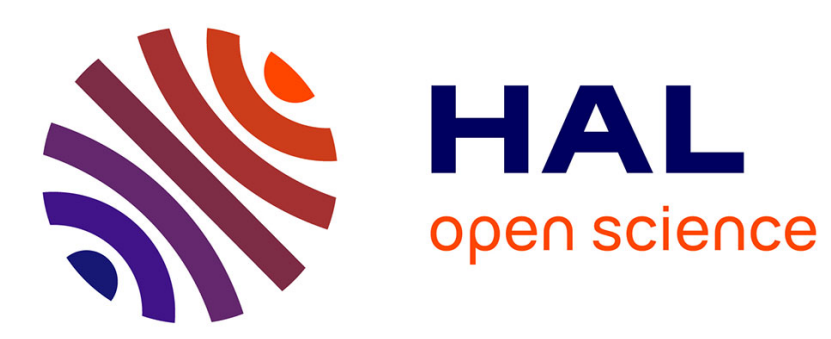

\title{
Determination of the elongational properties of polymers using a mixed numerical-experimental method
}

Laurent Robert, Samia Hmida Maamar, Vincent Velay, Fabrice Schmidt

\section{To cite this version:}

Laurent Robert, Samia Hmida Maamar, Vincent Velay, Fabrice Schmidt. Determination of the elongational properties of polymers using a mixed numerical-experimental method. ICEM13 - 13th International conference on experimental mechanics, Jul 2007, Alexanroupolis, Greece. 8 p., 10.1007/9781-4020-6239-1_331. hal-01818874

\section{HAL Id: hal-01818874 https://imt-mines-albi.hal.science/hal-01818874}

Submitted on 14 Mar 2019

HAL is a multi-disciplinary open access archive for the deposit and dissemination of scientific research documents, whether they are published or not. The documents may come from teaching and research institutions in France or abroad, or from public or private research centers.
L'archive ouverte pluridisciplinaire HAL, est destinée au dépôt et à la diffusion de documents scientifiques de niveau recherche, publiés ou non, émanant des établissements d'enseignement et de recherche français ou étrangers, des laboratoires publics ou privés. 


\title{
DETERMINATION OF THE ELONGATIONAL PROPERTIES OF POLYMERS USING A MIXED NUMERICAL-EXPERIMENTAL METHOD
}

\author{
L. Robert, S. Hmida-Maamar, V. Velay and F. Schmidt \\ Research Centre on Tools, Materials and Processes (CROMeP) \\ Ecole des Mines d'Albi-Carmaux, 81013 ALBI Cedex 9, France \\ \{laurent.robert,hmidahmi,vincent.velay,fabrice.schmidt\}@enstimac.fr
}

\begin{abstract}
The biaxial properties of materials such as rubbers or polymers are often difficult to identify, and generally a simple isotropic behaviour derived from classical 1D tensile test is considered. However, biaxial properties are useful for the simulation of plastic-processing operations such as blow moulding [1] or thermoforming. As previously reported, the rheological behaviour and the mechanical properties of rubbers and polymers can be obtained by using a bubble inflation rheometer [2-4], or multi-axial tensile test [5]. In this work, experimental data provided by optical measurements on tensile tests and bubble inflation tests are coupled with Finite Element Method simulations for identifying the rheological behaviour. This work is actually based on natural rubber and will be extend to thermoplastic (PP and PET) materials.
\end{abstract}

A bubble inflation rheometer has been developed in the laboratory. It allows to blow under controlled pressure rubber or thermoplastic membranes [2]: a circular membrane, clamped at the rim, is inflated by applying air pressure to its bottom face (see Fig. 1, left). In the case of thermoplastic, a heating step is necessary before applying the pressure. The heating can be performed by air convection, by conduction (heating cartridge at the rim) and by IR radiation.


FIGURE 1. Bubble inflation rheometer (detail, left) and shape contour extraction (right).

Two experimental optical techniques based on non-contact measurement by CCD cameras have been developed for in situ measurements: (i) images acquisition of the $2 \mathrm{D}$ projection of the bubble is done during the inflation process, giving shape contours versus inflated pressure (see Fig. 1, right); (ii) Digital Image Stereo-Correlation (DISC) [6] is applied using a calibrated stereo rig in order to obtain the three-dimensional description of the strain fields on the surface of the bubble. To perform DISC directly on the rubber bubble, several difficulties are to be solved (large level of deformation, semi-transparent aspect of the materials, lighting, etc.).

In addition, tensile tests have been performed using DISC due to the high level of strain. Tensile test performed on standard specimen give, on the one hand, the stress/strain curve. On the 
other hand, open hole tensile tests are performed on drilled specimen, putting in evidence nonhomogeneous strain fields measured by the optical full field method.

The Mooney-Rivling hyperelastic behaviour has been chosen for its simplicity ( 2 parameters) and because it is representative of natural rubbers behaviour, at least for reasonable stretch ratio $\lambda$ (no strain hardening). Fitting of the 1D stress/strain curve gives a set of parameters using eq. (1), numerical values obtained are $C_{10}=0.136 \mathrm{MPa}$ and $C_{01}=0.097 \mathrm{MPa}$.

$$
\frac{F}{S_{0}}=2 C_{10}\left(\lambda-\frac{1}{\lambda^{2}}\right)+2 C_{01}\left(1-\frac{1}{\lambda^{3}}\right)
$$

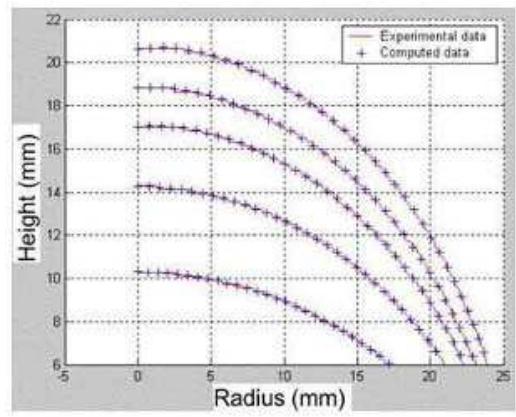

FIGURE 2. Experimental and numerical shape contours after optimization.

Then identification of the Mooney Rivling coefficients based on experimental shape contours using a Finite Element Model Updated (FEMU) procedure is performed using Abaqus ${ }^{\circledR}$. The cost function to minimise is defined as the norm (least squares sense) between experimental and numerical bubble shapes, and a Sequential Quadratic Programming (SQP) optimisation algorithm has been used. Results show that the Mooney-Rivling behaviour seems to be correct for small stretch ratio $(<200 \%)$ (see Fig. 2).

The second identification approach is based on a FEMU procedure using full field measurements by DISC (Vic-3D ${ }^{\circledR}$ ) during the open hole tensile test. Boundary conditions, cost function and preliminary results of the identification will be presented. Parameters values resulting from the identification based on the heterogeneous displacement field will be compared with those identified from the contour extractions and discussed.

\section{References}

1. Rosato, D.V. and Rosato, A.V., Blow molding handbook, $2^{\text {nd }}$ ed. Hanser, Munich, 2003.

2. Reuge, N., Schmidt, F.M., Lemaoult, Y., Rachik, M. and Abbe, F., Polym. Eng. Sci., Vol. 413, 522-531, 2001.

3. Li, Y., Nemes, J.A. and Derdouri, A.A., Polym. Eng. Sci., vol. 41-8, 1399-1412, 2001.

4. Jones, A., Shaw, J. and Wineman, A., Exp. Mech. vol 46-5, 579-587, 2006.

5. Chevalier, L. and Marco, Y., Polym. Eng. Sci., vol. 42-2, 280-298, 2002.

6. Garcia, D., Orteu, J.-J. and Penazzi, L., J. Mat. Proc. Tech., vol. 125, 736-742, 2002. 